This item was submitted to Loughborough's Research Repository by the author.

Items in Figshare are protected by copyright, with all rights reserved, unless otherwise indicated.

\title{
Safety format for the flexural design of tunnel fibre reinforced concrete precast segmental linings
}

PLEASE CITE THE PUBLISHED VERSION

https://doi.org/10.1016/j.tust.2020.103500

PUBLISHER

Elsevier

VERSION

AM (Accepted Manuscript)

\section{PUBLISHER STATEMENT}

This paper was accepted for publication in the journal Tunnelling and Underground Space Technology and the definitive published version is available at https://doi.org/10.1016/j.tust.2020.103500

\section{LICENCE}

CC BY-NC-ND 4.0

\section{REPOSITORY RECORD}

Cugat, V, Sergio Pialarissi-Cavalaro, JM Bairán, and A de la Fuente. 2020. "Safety Format for the Flexural Design of Tunnel Fibre Reinforced Concrete Precast Segmental Linings”. Loughborough University. https://hdl.handle.net/2134/12936869.v1. 


\title{
Safety format for the flexural design of tunnel fibre reinforced concrete precast segmental linings
}

\author{
V. Cugat, S.H.P. Cavalaro, J.M. Bairán, A. de la Fuente* \\ Universitat Politècnica de Catalunya (UPC), Department of Civil and Environmental \\ Engineering, Jordi Girona 1-3, C1, 08034.
}

\begin{abstract}
Fibre reinforced concrete (FRC) is increasingly used in tunnel segmental linings constructed with tunnel boring machines. Several codes include the FRC as a structural material and specific guidelines cover the design of FRC precast segmental linings. All of these consider the traditional limit state format, applying partial safety factors to the loads $\left(\gamma_{L}\right)$ and material strengths $\left(\gamma_{M}\right)$. Often, the $\gamma_{M}$ applied to the residual tensile strength of FRC is assumed the same as for concrete in compression. However, the variability in the determination of the residual tensile strength may be several times bigger than that of the compressive strength. In this context, the application of the same $\gamma_{M}$ should be revised as it could lead to reliability indexes lower than the established for traditional reinforced concrete structures. The objective of this paper is to estimate safety factors for the residual flexural response of FRC used in tunnels segments, considering the variability of the material in both the material characterisation test and in the real-scale structure. After a study about the influence of the element size on the variability, an evaluation of the structural reliability of the segmental linings made with FRC is performed using the FORM method and a database of real-scale test results compiled from existing literature. Based on that, values of $\gamma_{M}$ are proposed according to different failure consequences levels and relative economic costs required to increase the structural safety.
\end{abstract}

Keywords: fiber reinforced concrete, reliability, safety factor, post-cracking flexural strength, design

\section{Introduction}

So far, more than 70 tunnels have been successfully constructed with tunnel boring machines (TBM) and fibre reinforced concrete (FRC) segmental linings. During the service life, these tunnels tend to be subjected to dominant compressive stress patterns. Therefore, the reinforcement of the segments usually consists of a minimum amount established in codes to avoid brittle failure during transient loading situations (figure 1). In such cases, the partial or even the complete substitution of the traditional reinforcement by fibres may be a suitable alternative from the technical and economic standpoints (de la Fuente et al., 2012; Liao et al., 2015a; de la Fuente et al., 2017).

Several design codes (e.g. fib Model Code 2010) already include FRC as a structural material and specific guidelines are available for the design of FRC precast tunnel segments (e.g., ITAtech Report $n^{\circ} 7$ 2015, ACI 544.7R-16 report and fib Bulletin 83). These consider the semi-probabilistic safety format based on limit states with partial safety factors applied to the loads $\left(\gamma_{L}\right)$ and the material strengths $\left(\gamma_{M}\right)$. In the absence of specific proposal or studies, the $\gamma_{M}$ applied to the residual tensile strength of FRC is assumed the same as for concrete in compression, which is generally 1.50.

This contrasts with the significant difference in terms of variability in the assessment of the residual flexural tensile strength and the compressive strength. While typical compressive strength tests show coefficient of variance (CV) less than 8\%, bending tests normally used to characterise the flexural tensile response of FRC lead to CVs generally above $20 \%$. In this context, the application of the same $\gamma_{M}$ should be revised since it could lead to reliability indexes lower than the established for traditional reinforced concrete structures. 
The serviceability limit state (SLS) and the ultimate limit state (ULS) verifications vary depending on the load case and boundary conditions found in each stage of the segment production. For instance, demoulding, stocking, transporting and manipulation induce bending moments that might generate bending cracks. In contrast, the thrust applied by the jacks of the TBM might generate complex internal stresses distributions leading to splitting and bursting cracks (Liao et al., 2015b; Conforti et al., 2016).

Extensive research on the behaviour of precast fibre reinforced concrete segments (PFRCSs, hereinafter) subjected to the thrust of the jacks (Liao et al., 2015b; Conforti et al,. 2016; Meda et al., 2016), fire (Lilliu and Meda 2013; ), blast (Colombo et al., 2015; Colombo et al., 2016), bending (Plizzari and Tiberti, 2006; Caratelli et al., 2011; de la Fuente et al., 2012; Liao et al., 2015a; Liao et al., 2016), in situ loads (Molins and Arnau, 2011; Arnau and Molins 2011; Arnau and Molins 2012; Arnau and Molins 2015) and general design (Sorelli and Toutlemonde, 2005; Caratelli et al., 2012; Blanco et al., 2015; di Carlo et al., 2016) has been conducted. Likewise, research has also been performed regarding segment production tolerances (Cavalaro et al., 2012; Cavalaro et al., 2012) and FRC quality control by using the Barcelona test (Molins et al., 2009; Blanco et al., 2013; Pujadas et al., 2013; Pujadas et al., 2014; Carmona et al., 2016) and magnetic tests (Torrents et al., 2012, Cavalaro et al., 2015) to assess the amount and distribution of fibres. Nonetheless, to the knowledge of the authors, none of this extensive research includes aspects related to reliability and calibration of safety factors for the material design and particularly oriented to PFRCSs.

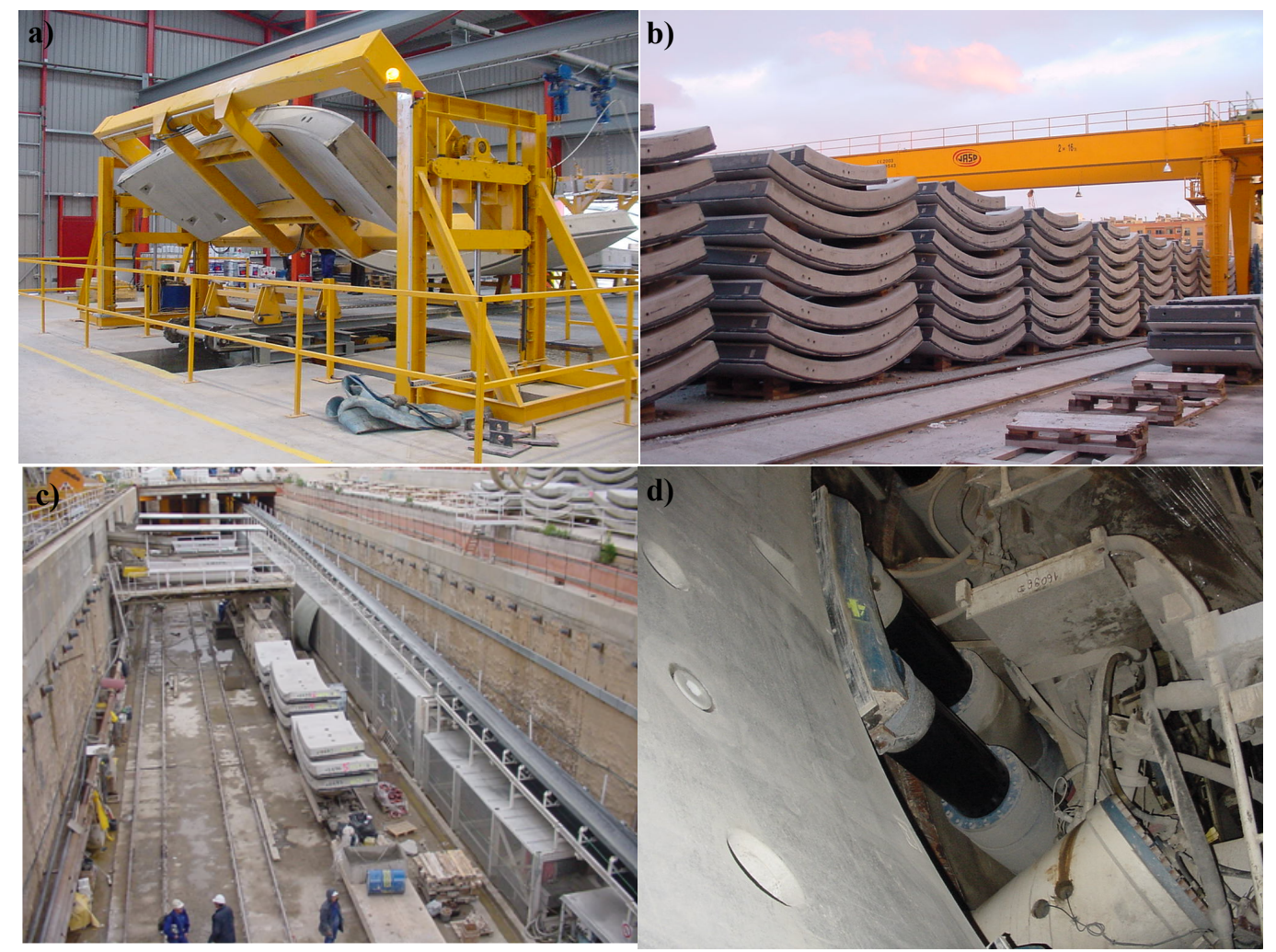

Figure 1. (a) Demoulding; (b) stocking; (c) transport and (d) jack's thrust

The objective of this paper is to estimate safety factors for the residual flexural response of FRC used in tunnels segments, considering the variability of the material. First, a study about the influence of the size of the element characterised on the variability is performed. Then, an evaluation of the structural reliability of the segmental linings made with FRC is conducted using the FORM method and a database compiled from the literature with test of real-scale elements. Based on that, values of $\gamma_{M}$ are proposed depending on the reliability index established. 
This work represents a step towards the safer application of FRC with structural responsibility in tunnel segments. Results and conclusions presented here provide a solid basis to support the revision of safety considerations for FRCfound in codes. Furthermore, this work may serve as a reference for future studies about the calibration of safety factors for other types of structures made with FRC.

\section{SCATTER OF RESIDUAL FLEXURAL RESPONSE AND CHARACTERISTIC VALUES}

Studies from the literature show that the scatter of the residual flexural response found in smallscale tests of FRC tends to reduce as the size of the element tested increases (Cavalaro and Aguado 2015; di Prisco et al., 2016a, di Prisco et al., 2016b). Consequently, the characteristic flexural response estimated from small-scale tests may differ from that found if real-scale elements were tested. To account for the influence of the size of the element in the scatter, the DAfStb proposes the factor $\boldsymbol{k}_{\boldsymbol{G}}^{f}$ calculated in Eq. 1 that depends on the area of the cross-section subjected to tension $\left(\boldsymbol{A}_{\boldsymbol{c} t}^{\boldsymbol{f}}\right.$ in

$\left.\mathrm{m}^{2}\right)$. $\boldsymbol{k}_{G}$ should be multiplied to the characteristic residual strength calculated from the small-scale bending test to assess the corrected characteristic value for the real-scale element. Consequently, the DAfStb modifies by the same extent both the average value and the coefficient of variation obtained in the small-scale test as both parameters are used to calculate the characteristic flexural residual strength prior to the application of $\boldsymbol{k}_{\boldsymbol{G}}^{\boldsymbol{f}}$.

$$
\boldsymbol{k}_{G}^{f}=1.0+0.5 \cdot \boldsymbol{A}_{\boldsymbol{c} t}^{f} \leq 1.7
$$

Cavalaro and Aguado 2015 evaluated the effect of the size of the element on the scatter based on numerous numerical analyses simulating the position and orientation of fibres in the cracked crosssection. The authors propose an equation to estimate the coefficient of variation used to calculate the characteristic value representative of the real-scale element using the coefficient of variation of the small-scale test. Differently from the approach defined by the DAfStb, the one proposed by Cavalaro and Aguado 2015 applies the correction directly to the coefficient of variation before the assessment of the characteristic value. Therefore, the influence of the size in the scatter is applied only to the coefficient of variation measured in the bending test, not the average value as in the case of DAfStb. This small difference might have significant practical and conceptual implications.

One could argue that, in addition to the specified in the DAfStb, $\boldsymbol{k}_{\boldsymbol{G}}^{f}$ also accounts for the influence of the size of the element on the average residual flexural strength. Nevertheless, if true, this would contradict common knowledge on the size-effect. According to numerous authors, the increase in size leads to a reduction in the average strength due to the higher likelihood of the influence of defects (Bazant 1984; Kim 1990; van Vliet and van Mier, 2000). Therefore, the multiplying factor applied to the average should be smaller than 1. Notice, however, that Eq. 1 leads to values always bigger than 1 .

A simplified analysis was performed to assess the influence of the size of the segment in the scatter of the residual tensile response. The procedure consists in dividing the cracked cross-section of a real-scale element (Figure 2) in smaller cells of $150 \times 150 \mathrm{~mm}^{2}$ - approximately equal to the cracked surface of the small-scale specimen of the 3-PBT (except the small compressed zone comprised within the neutral axis depth). The flexural residual tensile strength $\boldsymbol{f}_{R 3}$ for a crack mouth opening of $2.5 \mathrm{~mm}$ was assigned to each cell by a normal probability distribution with the average value $\left(\boldsymbol{\mu}_{\boldsymbol{B} T}\right)$ and the standard deviation $\left(\sigma_{\boldsymbol{B} T}\right)$ from the 3-PBT. The $\boldsymbol{f}_{\boldsymbol{F} t \boldsymbol{u}}$ of each cell was calculated as $\boldsymbol{f}_{\boldsymbol{R} 3} / \mathbf{3}$, according to the design approach defined in the fib Model Code 2010. After that, the bending moment capacity $\left(\boldsymbol{M}_{\boldsymbol{u}}\right)$ of the segment was determined by means of numerical integration, establishing 
the equilibrium and compatibility conditions (de la Fuente et al., 2012). Finally, $\boldsymbol{M}_{\boldsymbol{u}}$ was used to calculate the equivalent $\boldsymbol{f}_{R 3, e q}$ of the cross-section by considering a full-depth constant elastic-plastic residual tensile stress distribution of the FRC through the formula $\boldsymbol{f}_{\boldsymbol{R} 3, e q}=\mathbf{6 M}_{\boldsymbol{u}} / \boldsymbol{b} \square \boldsymbol{h}^{2}$.
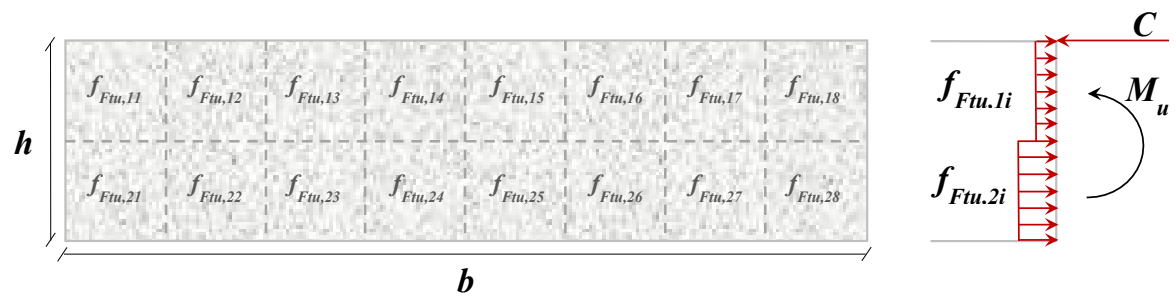

Figure 2. Scheme of a FRC specimen with a cross section of 1200x300 mm²

Each simulation with a particular cross-section size and probability distribution curve for the residual strength leads to a different $\boldsymbol{M}_{\boldsymbol{u}}$. Consequently, a different $\boldsymbol{f}_{\boldsymbol{R} 3, \boldsymbol{e}}$ is obtained every time a particular cross-section size is analysed using the same input parameters $\left(\boldsymbol{\mu}_{B T}\right.$ and $\left.\sigma_{B T}\right)$. The variation in the outcome of several analyses is related to the scatter in the post-cracking response due to the probabilistic definition of $\boldsymbol{f}_{R 3}$ of each cell. This enables the assessment of the average $\left(\boldsymbol{\mu}_{R S}\right)$ and the standard deviation $\left(\sigma_{R S}\right)$ of $f_{R 3, e q}$ for an element with a certain cross-section size. Notice that for an element with the same cross-section of the 3-PBT, $\mu_{R S}$ should be equal to $\mu_{B T}$ and $\sigma_{R S}$ should be equal to $\sigma_{B T}$.

A study was performed to determine the minimum number of repetitions needed to ensure an accurate assessment of $\mu_{R S}$ and $\sigma_{R S}$ for a particular cross-section size and input parameters. Figure 3 shows $\mu_{R S}$ and $\sigma_{R S}$ obtained for a cross-section with $300 \times 300 \mathrm{~mm}^{2}$ depending on the number of simulations. Bigger changes in the results are observed in case of less than 50,000 repetitions, whereas results remain nearly the same for bigger number of simulations. Changes of less than $0.3 \%$ were observed in the case of 300,000 simulations, which was taken as a reference for all geometries and input parameters analysed here.
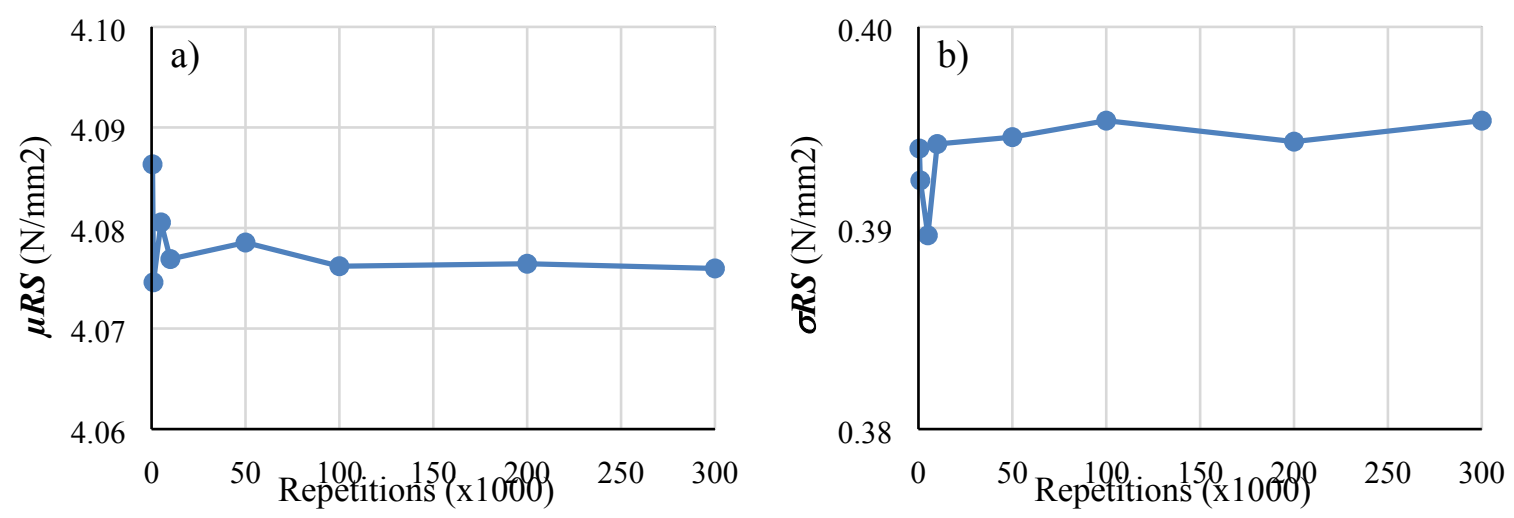

Figure 3. Influence of number of simulations on $\mu_{R S}$ and $\sigma_{R S}$

A parametric study was conducted to evaluate the size effect on the average and standard deviation considering the following input parameters: $\mu_{B T}$ of $3.60 \mathrm{MPa}, 4.26 \mathrm{MPa}$ and $4.80 \mathrm{MPa} ; \sigma_{B T}$ of $0.43 \mathrm{MPa}, 0.64 \mathrm{MPa}, 0.86 \mathrm{MPa}$ and $1.06 \mathrm{MPa}$; and cross-section sizes going from $150 \mathrm{x} 150 \mathrm{~mm}^{2}$ to $2250 \times 450 \mathrm{~mm}^{2}$. Notice that the analyses and regression presented in this section are limited to the simplified model and input values assumed in the parametric study. 
Figure 4 shows the influence of the width $(\boldsymbol{b})$ and the average of the small-scale 3-PBT $\left(\boldsymbol{\mu}_{\boldsymbol{B} T}\right)$ on $\boldsymbol{\mu}_{R S}$ and $\sigma_{R S}$ for series with $\sigma_{B T}$ equal to $0.77 \mathrm{MPa}$ and $\boldsymbol{h}$ equal to $150 \mathrm{~mm}$. The same trend was observed for other values of $\sigma_{B T}$ and $\boldsymbol{b}$ evaluated in the parametric study. $\boldsymbol{\mu}_{R S}$ remains approximately equal to $\boldsymbol{\mu}_{\boldsymbol{B} \boldsymbol{T}}$ regardless of $\boldsymbol{b}$ (see Figure 4a). This suggests that the average residual strength is independent of the width of the cross-section and dependent on the average assumed for the smallscale 3-PBT $\left(\boldsymbol{\mu}_{\boldsymbol{B} T}\right)$. On the contrary, $\sigma_{\boldsymbol{R} S}$ reduces with the increase of $\boldsymbol{b}$, as shown in Figure $4 \mathrm{~b}$. The same reduction is observed for all width values, regardless of the $\boldsymbol{\mu}_{\boldsymbol{B} T}$ assumed. This suggests that the $\sigma_{R S}$ is affected by the width of the segment and is independent of the average assumed for the smallscale 3-PBT $\left(\boldsymbol{\mu}_{\boldsymbol{B} T}\right)$.
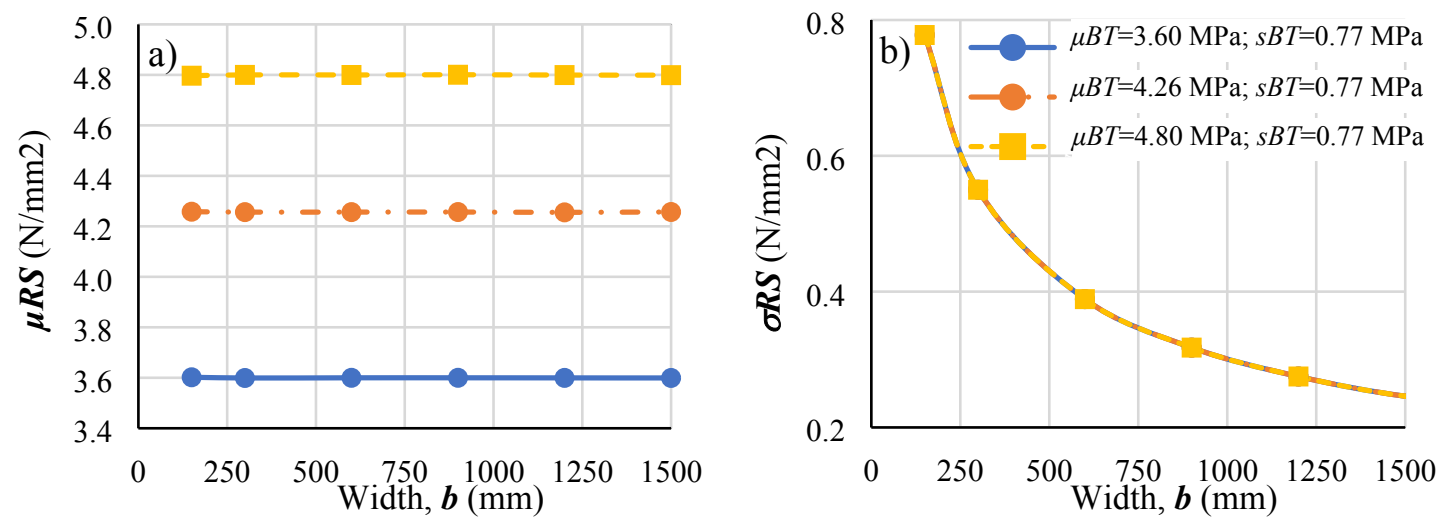

Figure 4. Influence of the $\boldsymbol{h}$ and $\boldsymbol{\mu}_{\mathrm{BT}}$ on $\boldsymbol{\mu}_{\mathrm{RS}}$ (a) and $\sigma_{\mathrm{RS}}(\mathrm{b})$

Figure $5 \mathrm{a}$ and $5 \mathrm{~b}$ show the influence of $\boldsymbol{h}$ and $\sigma_{\boldsymbol{B} T}$ on the average and standard deviation of the real-scale element $\left(\boldsymbol{\mu}_{R S}\right.$ and $\left.\sigma_{R S}\right)$, respectively. Only results from simulations with $\boldsymbol{\mu}_{B T}$ of $4.26 \mathrm{MPa}$ are presented. As expected, $\boldsymbol{\mu}_{R S}$ remains approximately equal to $\boldsymbol{\mu}_{B T}$ regardless of the cross-section size and $\sigma_{\mathbf{B T}}$ (see Figure 5a), thus revealing that these parameters do not affect the average estimated. Figure $5 \mathrm{~b}$ confirms that $\sigma_{R S}$ reduces as the size of the element increases and the scatter measured in the 3-PBT $\left(\sigma_{B T}\right)$ reduces. The fact that the cross-section size does not affect by the same extent $\boldsymbol{\mu}_{R S}$ and $\sigma_{R S}$ contradicts the approach of applying the same correction factor to $\boldsymbol{f}_{\boldsymbol{R} k}$ proposed in the DAfStb to account for the size effect as it modifies equally the average and the standard deviation.
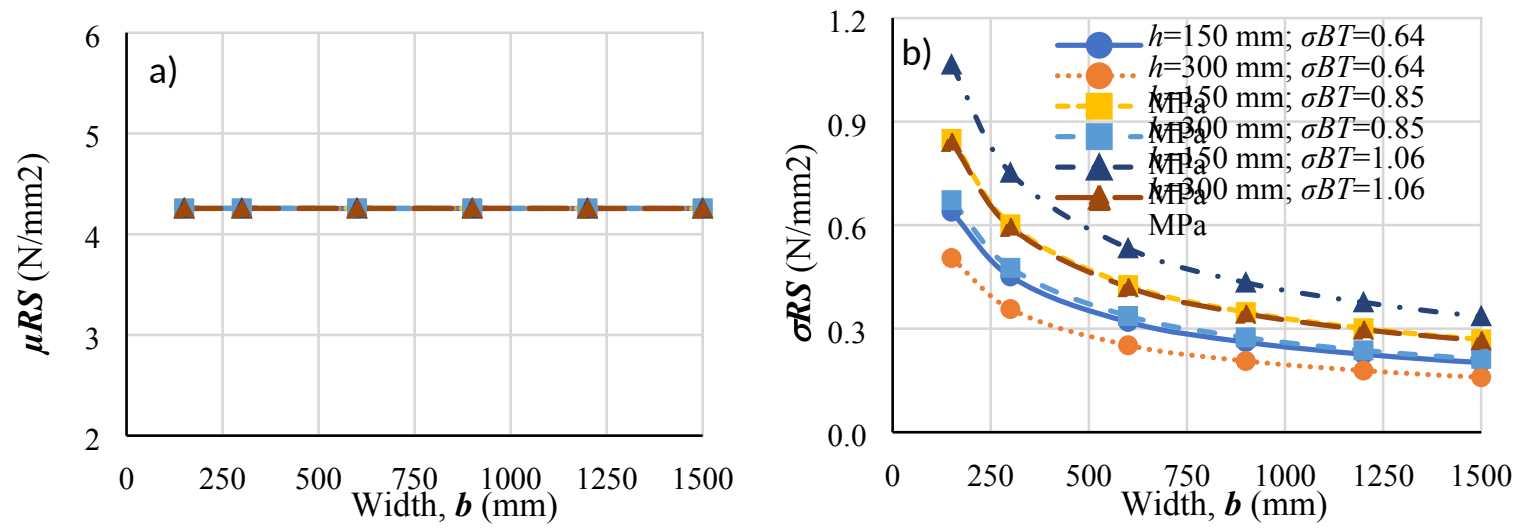

Figure 5. Influence of size of element in $\mu_{R S}$ (a) and $\sigma_{R S}$ (b) for different values of $\sigma_{B T}$ and $\boldsymbol{h}$

A multiple regression was performed using the results of the parametric study to find an equation that relates the standard deviation $\left(\sigma_{\boldsymbol{R} S}\right)$ of an element, the cross-section size $(\boldsymbol{b}$ and $\boldsymbol{h})$ and the standard deviation of the small-scale 3-PBT $\left(\sigma_{B T}\right)$. The equation selected was the same as proposed by 
Cavalaro \& Aguado (2015) that also studied the influence of these parameters in the scatter of the flexural response of FRC. The constants $\boldsymbol{k}_{1}, \boldsymbol{k}_{2}$ and $\boldsymbol{k}_{3}$ of the equation were calibrated through a nonlinear regression, giving the results shown in the final part of Eq. 2 with a $\mathrm{R}^{2}$ bigger than 0.99 . The high $\mathrm{R}^{2}$ found in this analysis is a consequence of considering results from the parametric study, which were obtained using the simplified model and the Monte Carlo analysis described here with a sufficiently big number of simulations for each scenario. The standard deviation obtained for the realscale element $\left(\sigma_{R S}\right)$ may be used in Eq. 3 to estimate the corresponding characteristic residual strength for the real-scale element $\left(f_{R k}\right)$. Notice that Eq. 3 considers $\mu_{R S}$ equal to $\boldsymbol{\mu}_{B T}$, based on the findings from the parametric study.

$$
\begin{aligned}
& \sigma_{R S}=k_{1} \cdot \sigma_{B T} \cdot h^{k_{2}} \cdot b^{k_{3}}=79 \cdot \sigma_{B T} \cdot h^{-0.37} \cdot b^{-0.50} \\
& f_{R k}=\mu_{B T}-1.645 \cdot \sigma_{R S}
\end{aligned}
$$

An example is proposed to compare the characteristic residual strength considering the size effect according to the DAfStb and to Eq. 3. The example contemplates a FRC with average residual strength $\left(\boldsymbol{f}_{\boldsymbol{R} \boldsymbol{m}}\right)$ of 4.0 MPa measured in the small-scale 3-PBT and a standard deviation $\left(\boldsymbol{\sigma}_{\boldsymbol{B} T}\right)$ of 0.8 $\mathrm{MPa}$, assuming that the cracked surface spreads over the entire cross-section subjected to bending for advanced loading stages. Since the consideration of the influence of the scatter in the DAfStb occurs after the calculation of $\boldsymbol{f}_{\boldsymbol{R} \boldsymbol{k}}$ for the small-scale 3-PBT element, the comparison is made in terms of the residual strength after the application of $\boldsymbol{k}_{G}^{f}$, thus representing the characteristic value corrected for the real-scale element. Other factors are considered the same for both approaches. The results are presented in Figure 6 for an element with a cracked cross section with height equal to $250 \mathrm{~mm}$ and width ranging from $125 \mathrm{~mm}$ to $5000 \mathrm{~mm}$.

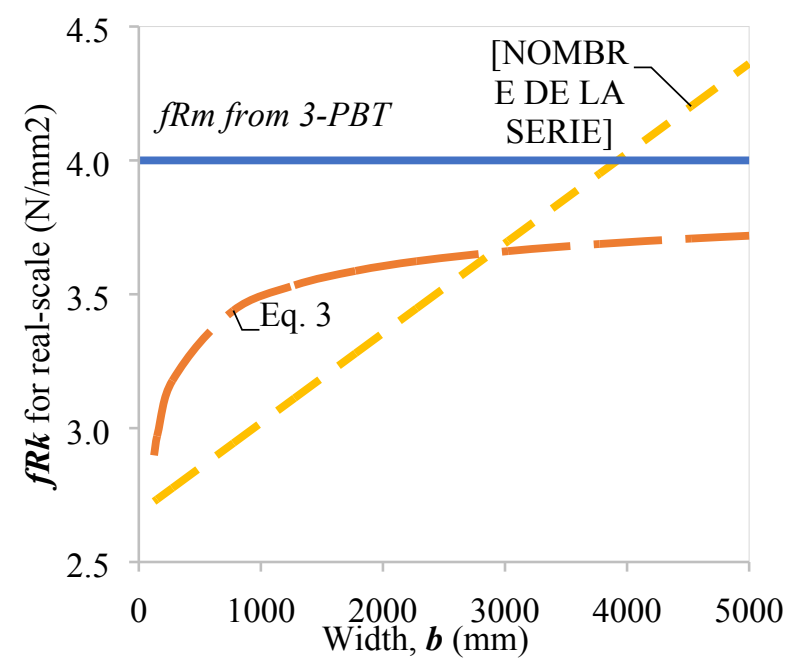

Figure 6. $f_{R k}$ values for the real-scale element according to the approach proposed in DAfStb and herein

Figure 6 reveals that the approach proposed in the DAfStb may provide $\boldsymbol{f}_{\boldsymbol{R} k}$ values bigger than the approach described here. The significant difference is also present in the shape of the curve. In the case of the alternative approaches proposed here, a stabilisation of the characteristic value takes place for $\boldsymbol{b}$ bigger than $2500 \mathrm{~mm}$, whereas the approach proposed in the DAfS tb increases linearly as long as $\boldsymbol{k}_{\boldsymbol{G}}^{f}$ is below 1.7. For a width of $5000 \mathrm{~mm}$, the corrected characteristic residual strength predicted according to the DAfStb is 1.17 times bigger than the obtained using Eq. 3. In fact, for this 
width the characteristic value in the case of the DAfStb is $5.45 \mathrm{MPa}$ (for a $\boldsymbol{k}_{\boldsymbol{G}}^{f}$ of 1.625), which is even bigger than the average residual strength of the small-scale test considered in the example. This represents a potential inconsistency, as the characteristic value of the real-scale element could hardly be bigger than the average measured in the small-scale 3-PBT.

\section{CALIBRATION OF THE MATERIAL PARTIAL SAFEY FACTOR}

\subsection{Procedure and assumptions}

The critical design situation commonly found in FRC tunnel segments occurs during transient stages (e.g., production, transport or installation) with a typical failure due to bending. Enough safety margin remains after construction given the typical predominance of compressions and relatively small bending moments. In most cases, the design bending moment $\left(\boldsymbol{M}_{\boldsymbol{d}}\right)$ attributed to transient load is smaller than the cracking bending moment $\left(\boldsymbol{M}_{\boldsymbol{c} r}\right)$. Therefore, segments are generally designed not to crack in transient stages, fulfilling minimum ductility requirements. The design criterion to derive the required $\boldsymbol{f}_{\boldsymbol{R} 3}$ consists of imposing $\boldsymbol{M}_{\boldsymbol{u}} \geq \boldsymbol{M}_{\boldsymbol{c}}$ (Liao et al., 2015a and Liao et al., 2016), which is consistent with the supracritial and critical curves found in the moment $(\boldsymbol{M})$ - curvature $(\chi)$ relationship from Figure 7 ( fib Bulletin 83). This should guarantees a ductile behaviour of the segment provided by the fibres in the event of cracking (Chiaia et al., 2009a,b; Fantilli et al., 2016a,b). Such procedure is consistent with the safety format and ductility requirements used for traditional reinforced concrete (Levi 1985).

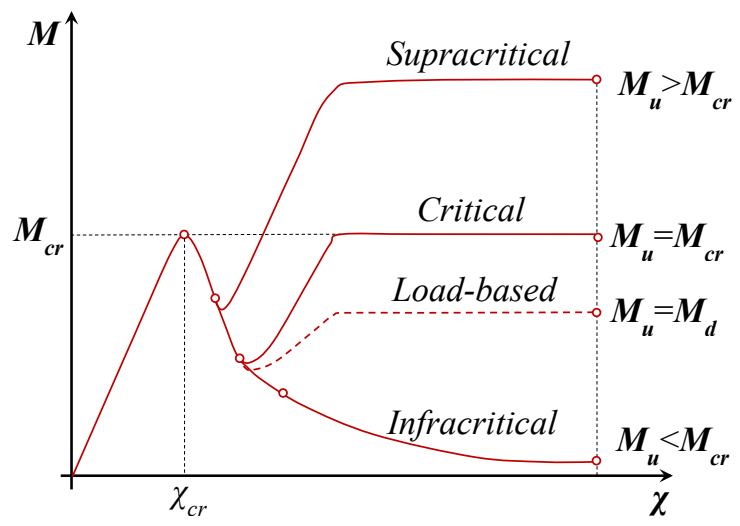

Figure 7. Moment $(\boldsymbol{M})$ - curvature $(\boldsymbol{\chi})$ relationship of a cross-section with different reinforcement configurations

A reliability analysis was performed to calibrate the partial safety factor applied to $f_{R}$ in the design of transient loading situations of FRC segments subjected to bending. The calculation of the reliability index $(\boldsymbol{\beta})$ was conducted through the FORM method (Melchers, 1999). This method requires the definition of the limit state function ( $\boldsymbol{g}$-function) that relates the resistance $(\boldsymbol{R})$ and the actions $(\boldsymbol{Q})$ applied to the segment, represented by probability density functions given their stochastic nature. The failure occurs for $\boldsymbol{g}<0$, being $\boldsymbol{g}=0$ the limit situation represented in Eq. 4 . The resistance is represented by the ultimate bending moment $\boldsymbol{M}_{\boldsymbol{u}}$ (assessed by means of Eq. 5), whereas the load resisted is the cracking bending moment $\left(\boldsymbol{M}_{c r}\right)$ calculated with Eq. 6, in which $\left(\boldsymbol{f}_{\text {ct.ffl }}\right)$ is the tensile flexural strength of concrete.

$$
g(R, Q)=R-Q=M_{u}-M_{c r}
$$




$$
\begin{aligned}
& M_{\boldsymbol{u}}=\frac{b h^{2}}{6} \boldsymbol{f}_{\boldsymbol{R} 3} \\
& M_{\boldsymbol{c r}}=\frac{\boldsymbol{b h ^ { 2 }}}{6} \boldsymbol{f}_{\boldsymbol{c t}, \boldsymbol{f l}}
\end{aligned}
$$

Eq. 4-6 are combined to derive Eq. 7 that gives the simplified $g$-function compatible with the considerations mentioned above for the segments. If $g>0, f_{R 3}$ should guarantee a supracritical failure while if $\boldsymbol{g}=0$, the failure is critical - both complying with the ductility requirements. The model bias factor $(\lambda)$ is the ratio $\boldsymbol{M}_{u, e x p} / \boldsymbol{M}_{u, e s t}$, where $\boldsymbol{M}_{u, \text { exp }}$ is the bending moment of the real-scale FRC segment obtained experimentally for a midspan CMOD of $2.5 \mathrm{~mm}$ and $\boldsymbol{M}_{u, e s t}$ is the bending moment of the same segment estimated with Eq. 5.

$$
g\left(M_{w}, M_{c r}\right)=\lambda \cdot f_{R 3}-f_{c t, f l}
$$

The design value of $f_{R 3}\left(f_{R 3 d}\right)$ in ULS is calculated as the ratio $f_{R 3 k} / \gamma_{f R 3 k}$, where $\gamma_{f R 3 k}$ is the partial safety factor applied to $\boldsymbol{f}_{\boldsymbol{R} 3 \boldsymbol{k}}$. The average flexural tensile strength $\left(\boldsymbol{f}_{c t m, f l}\right)$ is calculated as $\boldsymbol{f}_{c t m} \cdot(1.6-\boldsymbol{h})$, which depends on the height $\boldsymbol{h}$ of the cross-section and the average tensile strength $\boldsymbol{f}_{\text {ctm }}$ calculated as $0.30 \cdot f_{c k}{ }^{2 / 3} \cdot f_{c t m}$ is usually considered the representative value of $\boldsymbol{f}_{c t}$ in terms of cracking onset according to most codes and existing formulations for assessing minimum reinforcement to guarantee crosssectional ductility (Carpinteri et al., 2014). Including these considerations in Eq. 7 for $\boldsymbol{g}=0$ leads Eq. 8 , which represents the limit state equation used to calibrate the global safety factor $\left(\gamma_{f R 3 k}\right)$ of a critical section subjected to bending. This safety factor is meant to consider the variability (of $\boldsymbol{h}, \boldsymbol{f}_{c t}$ and $\boldsymbol{f}_{\boldsymbol{R} 3}$ ) of both resistance $\left(\boldsymbol{M}_{\boldsymbol{u}}\right)$ and demand parts $\left(\boldsymbol{M}_{\boldsymbol{c}}\right)$ in ULS.

$$
\frac{f_{R 3 k}}{\gamma_{f R 3 k}}=f_{c t m} \cdot(1.6-h)
$$

The reliability index $(\boldsymbol{\beta})$ was computed for different values $\gamma_{f R 3 k}$ in a representative set of design cases (concrete classes ranging from C25 to C60 and segment heights $\boldsymbol{h}$ varying between $200 \mathrm{~mm}$ and 400). Table 1 shows both the random variables and the probability density functions (JCSS 2001) considered in the reliability analysis.

Table 1. Random variables and probability density functions used in reliability analysis

\begin{tabular}{|c|c|c|c|c|}
\hline Variable & Description & Distribution & $\begin{array}{c}\text { Mean } \\
(\boldsymbol{\mu})\end{array}$ & $\begin{array}{c}\text { Standard } \\
\text { deviation }(\boldsymbol{\sigma})\end{array}$ \\
\hline $\boldsymbol{\lambda}$ & Model bias factor & Log-normal & 1.04 & $0.33 \boldsymbol{\mu}$ \\
\hline $\boldsymbol{f}_{c t, f l}$ & $\begin{array}{c}\text { Flexural tensile } \\
\text { strength }\end{array}$ & Log-normal & $\begin{array}{c}\text { According to } \\
\text { concrete class }\end{array}$ & $0.30 \boldsymbol{\mu}$ \\
\hline $\boldsymbol{h}$ & Geometry error & Normal & 0.0 & $10 \mathrm{~mm}$ \\
\hline $\boldsymbol{f}_{\boldsymbol{R} 3}$ & $\begin{array}{c}\text { Post-cracking stress } \\
\text { for CMOD=2.5mm }\end{array}$ & Log-normal & $\begin{array}{c}\text { According to } \\
\text { design }\end{array}$ & $\begin{array}{c}\text { Assessed } \\
\text { experimentally }\end{array}$ \\
\hline
\end{tabular}

\subsection{Experimental programs considered to calibrate $\lambda$}

A review of the scientific literature was performed to collect the experimental results needed to calibrate a reliable function for $\lambda$. The aim was to find real-scale bending tests of FRC segments without traditional reinforcement under simply supported configuration analogous to that shown in Figure 8. A total of 23 full-scale bending tests on simply supported FRC segments with complete information (e.g., geometry, FRC mechanical characterization, and force-displacement curves) were found and considered for this purpose. 
Table 2 shows a list with the main characteristics and the $\lambda$ estimated in each case. Both the average $\left(\lambda_{m}\right)$ and the coefficient of variation $\left(\mathbf{C} \mathbf{V}_{\lambda}\right)$ of the bias factor were assessed for segments with the same fibre content $\left(\boldsymbol{C}_{f}\right)$. Values of $\lambda_{m}$ are predominantly higher than 1.00. This means that the analytical model proposed to assess $\boldsymbol{M}_{\boldsymbol{u}}$ (Eq. 5) leads to results on the safe side with respect to the experimental results. The global $\lambda_{m}$ is 1.04 , with a coefficient of variation of $33 \%$.

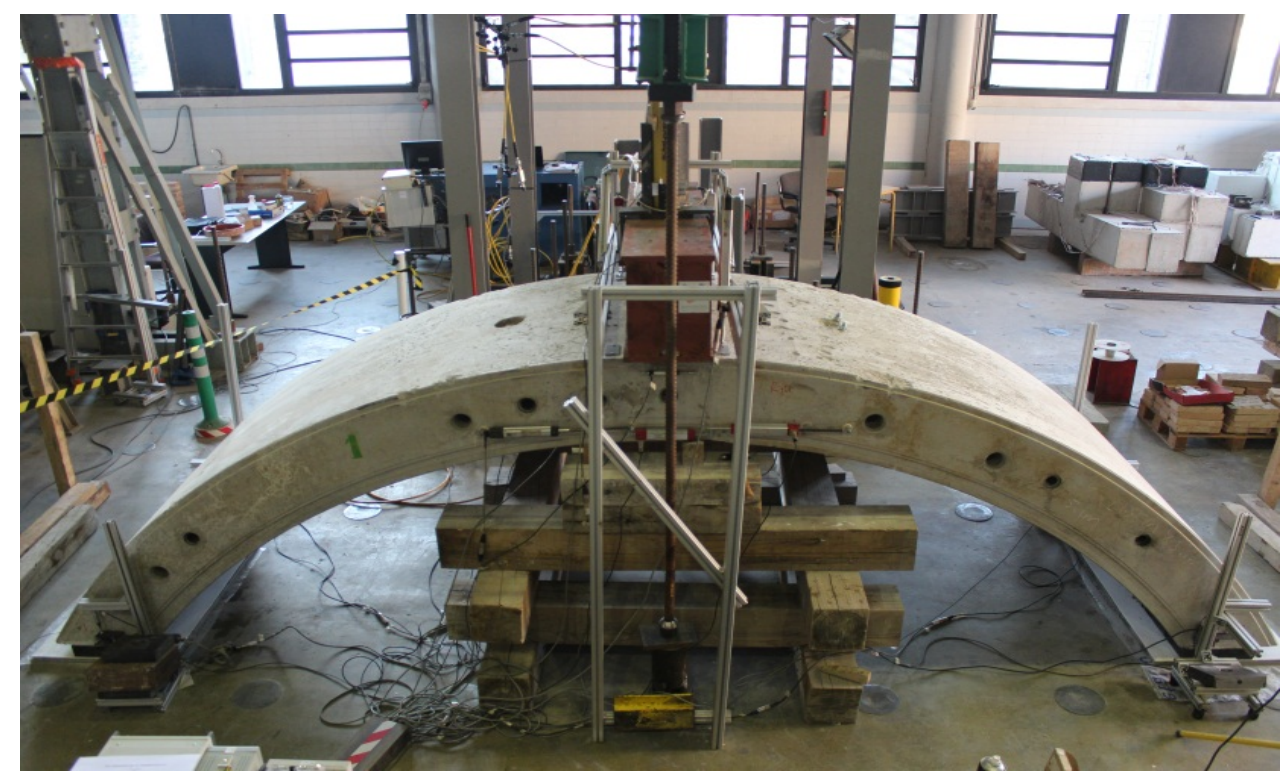

Figure 8. Typical full-scale bending test of a FRC segment considered to assess $\lambda$

Table 2. Experimental programs of real-scale bending tests of FRC tunnel segments

\begin{tabular}{|c|c|c|c|c|c|c|c|c|c|}
\hline Elements & $\begin{array}{l}\text { No. } \\
\text { tests }\end{array}$ & $\begin{array}{c}\boldsymbol{f}_{c} \\
(\mathrm{MPa})\end{array}$ & $\begin{array}{c}\text { Dimensions } \\
(\mathrm{mm})\end{array}$ & $\begin{array}{c}\boldsymbol{C}_{\boldsymbol{f}} \\
\left(\mathrm{kg} / \mathrm{m}^{3}\right)\end{array}$ & $\boldsymbol{\theta}_{f} / \lambda_{f}$ & $\begin{array}{c}\boldsymbol{f}_{\boldsymbol{R} 3 \boldsymbol{m}} \\
(\mathrm{MPa})\end{array}$ & $\lambda$ & $\lambda_{m} / \mathbf{C V}$ & Reference \\
\hline \multirow{3}{*}{$\begin{array}{l}\text { PS } \\
\text { (MT) }\end{array}$} & \multirow{3}{*}{4} & \multirow{3}{*}{50} & \multirow{3}{*}{$2300 \times 1800 \times 350$} & 45 & \multirow{3}{*}{$1.00 / 50$} & \multirow{2}{*}{3.82} & 0.92 & \multirow{2}{*}{$1.20 / 0.33$} & \multirow{3}{*}{ Gettu et al., 2004} \\
\hline & & & & 4J & & & 1.48 & & \\
\hline & & & & 60 & & 4.87 & $\frac{1.31}{0.92}$ & $1.11 / 0.25$ & \\
\hline $\mathrm{S}(\mathrm{RP})$ & 1 & 55 & $3000 \times 1000 \times 400$ & 20 & $0.55 / 64$ & 0.91 & 1.35 & $1.35 /-$ & Galeote et al., 2018 \\
\hline \multirow{3}{*}{ PS (MT) } & \multirow{3}{*}{3} & \multirow{3}{*}{45} & \multirow{3}{*}{$3888 \times 1500 \times 300$} & 35 & \multirow{3}{*}{$0.67 / 60$} & 3.89 & 1.93 & $1.93 /-$ & \multirow{3}{*}{ Bittencourt et al., 2016} \\
\hline & & & & 40 & & \multirow{2}{*}{4.60} & 1.15 & $1.15 /-$ & \\
\hline & & & & 40 & & & 0.94 & $0.94 /-$ & \\
\hline \multirow{2}{*}{ PS (VS) } & \multirow{2}{*}{2} & 50 & \multirow{2}{*}{$5500 \times 1200 \times 350$} & 45 & \multirow{2}{*}{$1.00 / 50$} & 3.84 & 0.90 & $0.90 /-$ & \multirow{2}{*}{ Liao et al., 2016} \\
\hline & & 50 & & 50 & & 5.58 & 0.51 & $0.51 /-$ & \\
\hline PS (RP) & 1 & 60 & $3180 \times 1500 \times 235$ & 35 & $0.75 / 80$ & 3.01 & 1.23 & $1.23 /-$ & Abbas et al., 2014 \\
\hline \multirow{6}{*}{ PS (MT) } & \multirow{6}{*}{6} & \multirow{6}{*}{60} & \multirow{6}{*}{$3243 \times 1500 \times 235$} & \multirow{6}{*}{57} & \multirow{6}{*}{$0.75 / 80$} & \multirow{6}{*}{7.68} & 0.66 & \multirow{6}{*}{$0.76 / 0.18$} & \multirow{6}{*}{ Blazejowsky, 2014} \\
\hline & & & & & & & 0.81 & & \\
\hline & & & & & & & 0.77 & & \\
\hline & & & & & & & 0.80 & & \\
\hline & & & & & & & 0.57 & & \\
\hline & & & & & & & 0.96 & & \\
\hline \multirow{6}{*}{ PS (RT) } & & & & & & & 0.89 & & \\
\hline & & & & 30 & & 2.60 & 1.04 & $0.87 / 0.22$ & \\
\hline & 6 & 60 & $2359 \times 1400 \times 350$ & & $075 / 80$ & & 0.67 & & Pohetal 2000 \\
\hline & 0 & 80 & 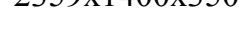 & & $0.17 / 00$ & & 1.33 & & 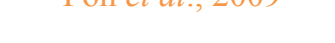 \\
\hline & & & & 40 & & 2.40 & 1.48 & $1.37 / 0.07$ & \\
\hline & & & & & & & 1.31 & & \\
\hline
\end{tabular}


PS: Precast Segment; MT: Metro Tunnel; S: Slab; RP: Research Project; RT: Road Tunnel; VS: Vertical Shaft; $\boldsymbol{f}_{c}$ : concrete compressive strength; $f_{R 3 m}$ : mean post-cracking flexural strength of the FRC $(\mathrm{CMOD}=2.5 \mathrm{~mm}) ; C_{f}$. Fibre content $\emptyset_{f}$. Fiber diameter; $\lambda_{f}$ : Fiber aspect ratio.

\section{RESULTS AND DISCUSSION}

Figure 9 shows the relationship $\boldsymbol{\beta}-\boldsymbol{\gamma}_{f R 3 \boldsymbol{k}}$ obtained with the FORM method for $\mathbf{C V}$ of $\boldsymbol{f}_{\boldsymbol{R} 3}$ ranging from 10 to $30 \%$. Values of $\mathbf{C V}$ between $10 \%$ and $15 \%$ are generally found in FRC with a high homogeneity or in elements with width $\boldsymbol{b}>1000 \mathrm{~mm}$ whilst $\mathbf{C V}$ between $15 \%$ and $25 \%$ correspond to a normal FRC in elements with small cross-sections (Pujadas et al., 2013 and Pujadas et al., 2014). As expected, the increase in the $\mathbf{C V}$ causes a reduction of $\boldsymbol{\beta}$. For the $\gamma_{f R 3 k}=1.50$ commonly used in the design of FRC elements in ULS, $\boldsymbol{\beta}$ ranges from 1.5 for a CV of $30 \%$ to 2.4 for a CV of $10 \%$.

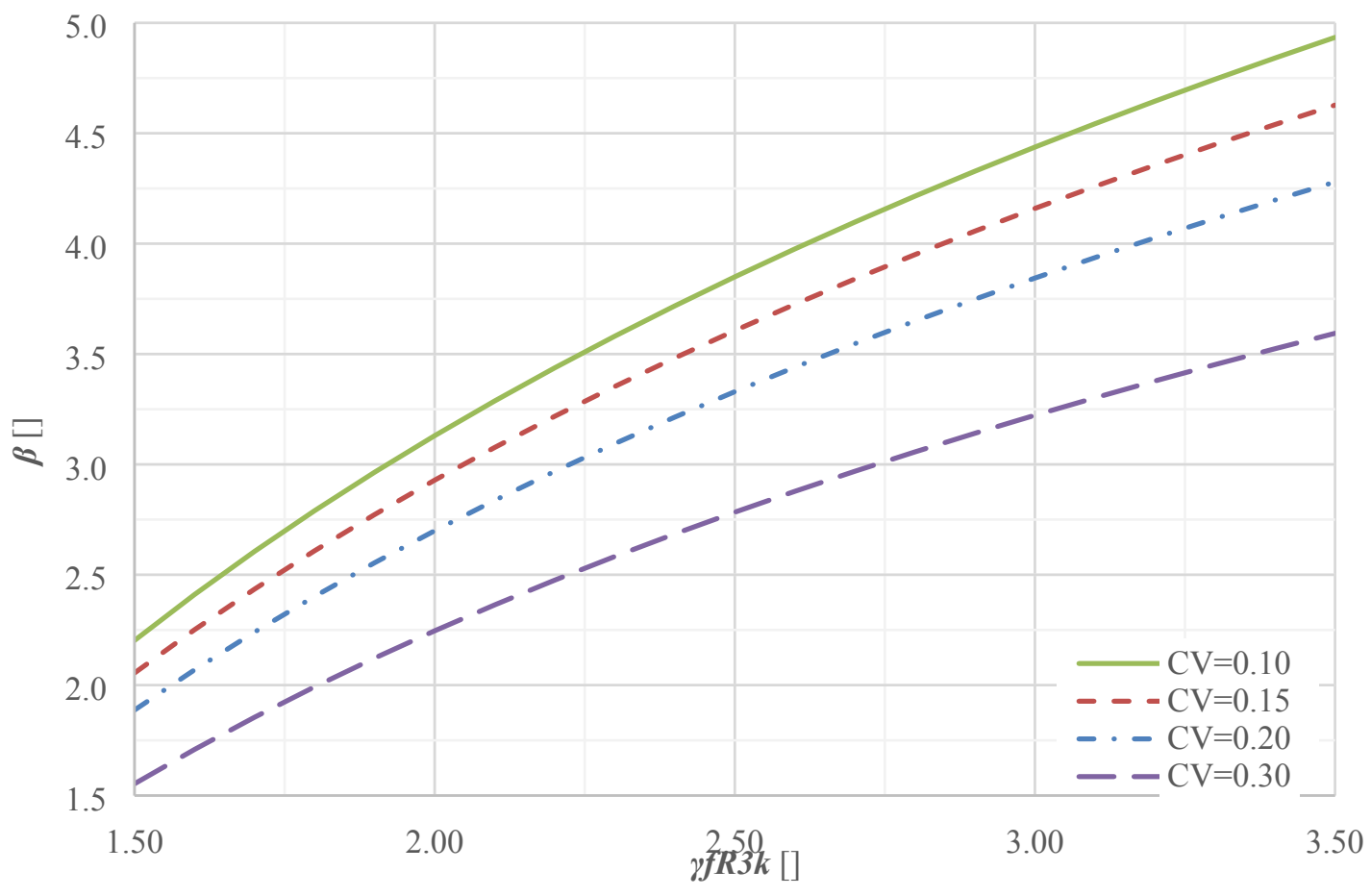

Figure 9. Relationship between $\boldsymbol{\beta}-\gamma_{f R 3 k}$ for FRC tunnel segments subjected to flexure in ULS

A multivariable regression was performed using the data from the parametric study to adjust an exponential equation (ECP-ASBL 2018, Schlune et al., 2011 and Cervenka, 2013) that relates $\boldsymbol{\gamma}_{f R 3 \boldsymbol{k}}$ with the $\boldsymbol{\beta}$ established in the guidelines (or in the project) and the standard deviation of $\boldsymbol{f}_{\boldsymbol{R} 3}$ for the real scale element. Eq. 9 shows the result of the fit $\left(\mathbf{R}^{2} \geq 0.90\right)$, which may be used to assess $\gamma_{f R 3 k}$ for specific cases. Notice that the application of this equation is limited to $\mathbf{C V}$ ranging from $10 \%$ to $30 \%$ and $\boldsymbol{\beta}$ ranging from 1.5 to 5.0 .

$$
\gamma_{f_{R 3 k}}=0.80 e^{0.56 \boldsymbol{\beta} \cdot \boldsymbol{C} \boldsymbol{f}_{R 3}^{0.27}}
$$

The $\boldsymbol{\beta}$ selected for each application depends mainly on the type of design, the consequences of the failure and the cost of applying safety measures. Guidelines establish reference values for $\boldsymbol{\beta}$ to be considered, which are implicit in the partial safety factors (loads and strengths) traditionally used in the design of reinforced/prestressed concrete structures. Herein, the values included in the EN 
1990:2002+A1 and in the fib Model Code 2010 are taken to calibrate $\boldsymbol{\gamma}_{f \boldsymbol{R} 3 \boldsymbol{k}}$. Table 3 summarizes the $\gamma_{f R 3 k}$ calculated with Eq. 9 for different scenarios. All assessments were made assuming a $\mathbf{C V}$ of $12 \%$.

Notice that the same coefficients could also be applied to other FRC elements different from tunnel segments if two conditions are fulfilled: the element is reinforced only with fibres and the design bending moment $\left(\boldsymbol{M}_{\boldsymbol{d}}\right)$ is smaller than the cracking bending moment $\left(\boldsymbol{M}_{\boldsymbol{c r}}\right)$. Notice that these conditions are met in other precast concrete products reinforced only with fibres, so this results can be extrapolated to other elements.

\begin{tabular}{|c|c|c|c|c|c|}
\hline \multirow{2}{*}{ Period } & \multirow{2}{*}{$\begin{array}{l}\text { Relative cost of } \\
\text { safety measure }\end{array}$} & \multicolumn{4}{|c|}{ Consequences of failure } \\
\hline & & Minor & Some & Moderate & Large \\
\hline \multirow{3}{*}{1 year } & Large (A) & $\begin{array}{l}1.65 \\
(2.3)\end{array}$ & $\begin{array}{l}2.06 \\
(3.0)\end{array}$ & $\begin{array}{l}2.42 \\
(3.5) \\
\end{array}$ & $\begin{array}{l}2.92 \\
(4.1)\end{array}$ \\
\hline & Normal (B) & $\begin{array}{l}2.00 \\
(2.9) \\
\end{array}$ & $\begin{array}{l}2.42 \\
(3.5) \\
\end{array}$ & $\begin{array}{l}2.92 \\
(4.1) \\
\end{array}$ & $\begin{array}{l}3.53 \\
(4.7) \\
\end{array}$ \\
\hline & Small (C) & $\begin{array}{l}2.42 \\
(3.5) \\
\end{array}$ & $\begin{array}{l}2.92 \\
(4.1) \\
\end{array}$ & $\begin{array}{l}3.53 \\
(4.7) \\
\end{array}$ & $\begin{array}{l}4.01 \\
(5.1) \\
\end{array}$ \\
\hline \multirow{3}{*}{$\begin{array}{c}50 \\
\text { years }\end{array}$} & Large (A) & $\begin{array}{l}1.00 \\
(0.0) \\
\end{array}$ & $\begin{array}{l}1.28 \\
(1.5) \\
\end{array}$ & $\begin{array}{l}1.65 \\
(2.3) \\
\end{array}$ & $\begin{array}{l}2.13 \\
(3.1) \\
\end{array}$ \\
\hline & Normal (B) & $\begin{array}{l}1.21 \\
(1.3) \\
\end{array}$ & $\begin{array}{l}1.65 \\
(2.3) \\
\end{array}$ & $\begin{array}{l}2.13 \\
(3.1) \\
\end{array}$ & $\begin{array}{l}2.66 \\
(3.8) \\
\end{array}$ \\
\hline & Small (C) & $\begin{array}{l}1.65 \\
(2.3)\end{array}$ & $\begin{array}{l}2.13 \\
(3.1)\end{array}$ & $\begin{array}{l}2.66 \\
(3.8)\end{array}$ & $\begin{array}{l}3.11 \\
(4.3)\end{array}$ \\
\hline
\end{tabular}

It should be pointed out that the target $\boldsymbol{\beta}$ considered in ULS may be different, this based upon the relation between the consequence of failure and the cost of the safety measure. In particular, in the case of tunnel segments, the probability of reaching the cracking load is small as the design is oriented to guarantee ratios $\boldsymbol{M}_{\boldsymbol{c r}} / \boldsymbol{M}_{\boldsymbol{d}}>1.00$, (considering $\boldsymbol{f}_{\text {ctk,fl }}$ ). Even if cracking occurs, the anticipated consequences are limited. Machinery is used to demould and move the segment during production and installation so that workers keep a safe distance during transient stages. Consequently, the risk to the safety of workers is small. Moreover, the structural safety in service conditions are not likely to be compromised in tunnels subjected mainly to compression. If significant cracking takes place, the segments could be rejected before installation in the tunnel, thus minimizing the impact on the structural reliability during the service life (cracks, however, can occur during the TBM thrust phase). Therefore, the consequence of failure is deemed as "Some" in this case according to Table 3.

On the other hand, the consideration of additional precautionary measures would imply a "Normal" increase in cost of production or material cost of the segment, leading to large relative total costs. Considering both aspects and a period of 50 years in Table 3 yields a $\gamma_{f R 3 k}$ of 1.65 . This is $10 \%$ bigger than the used in current guidelines for the design of FRC elements.

An alternative approach for establishing $\boldsymbol{\beta}$ consist in comparing with current accepted design in similar situations. In this sense, design codes for reinforced concrete (RC) structures require a minimum longitudinal reinforcement to prevent from brittle failure (guarantee a ductile response) in case of cracking caused by bending. Hence, a plausible approach to define $\gamma_{f R 3 k}$ would consist in selecting the $\boldsymbol{\beta}$ that provides similar target reliability to brittle failure accepted in the current provisions for RC. 
The current minimum longitudinal reinforcement in RC, according to Eurocode 2 (EN 1992:2004), is given by Eq. (10). The limit-state function for ductile response ( $\boldsymbol{g} \geq 0)$ is Eq. 11, where $\boldsymbol{M}_{\boldsymbol{u}}\left(\boldsymbol{A}_{\boldsymbol{s}, \boldsymbol{m i n}}\right)$ is the resisting bending moment when the minimum reinforcement amount $\left(\boldsymbol{A}_{\boldsymbol{s}, \boldsymbol{m i n}}\right)$ derived from Eq. 10 is provided. $\boldsymbol{\beta}$ for a $\mathrm{C} 30 / 37$ concrete is shown in Figure 10 as function of the crosssectional effective depth $(\boldsymbol{d})$. The characteristic value of the steel yielding strength $\left(\boldsymbol{f}_{\boldsymbol{y} k}\right)$ considered was $500 \mathrm{MPa}$, along with $\log$-normal distribution $\left(f_{y m}=550 \mathrm{MPa}\right.$ and $\left.\mathbf{C V}=5.5 \%\right)$.

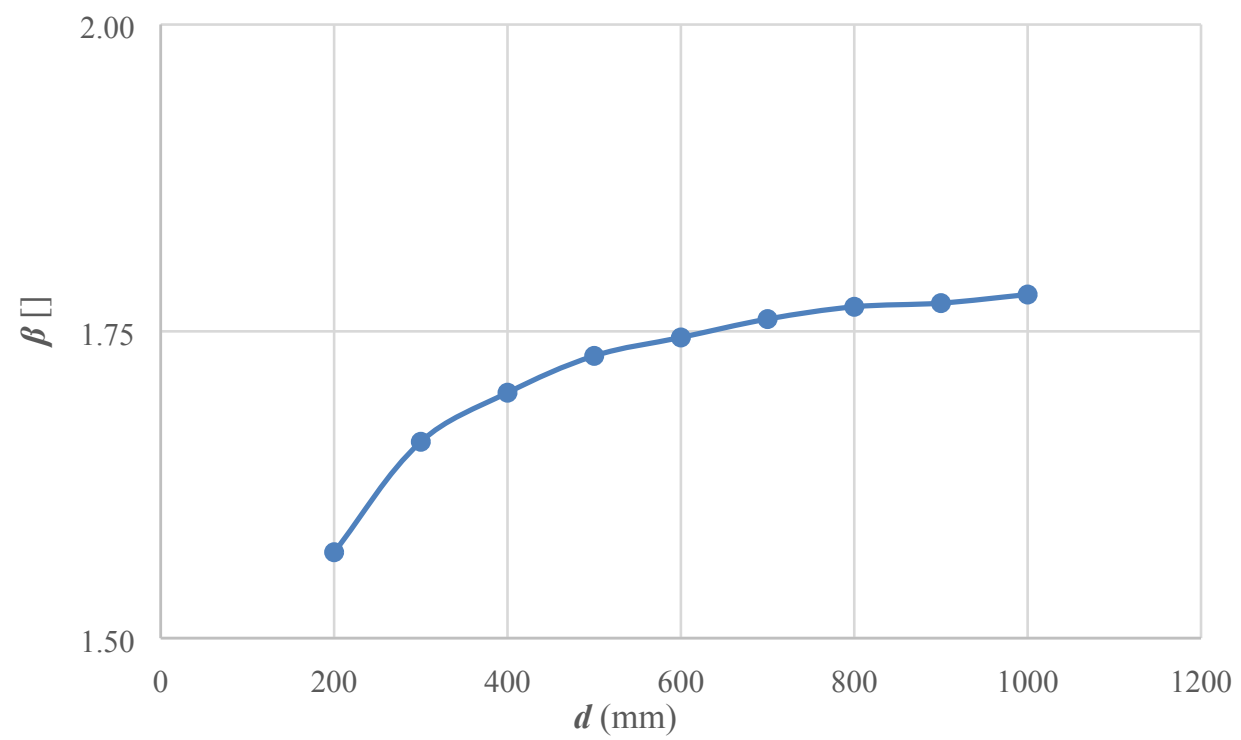

Figure 10. Reliability index against brittle failure in RC elements designed with minimum reinforcement

$$
\begin{aligned}
& \boldsymbol{A}_{\boldsymbol{s}, \min }=0.26 \frac{\boldsymbol{f}_{c t m}}{\boldsymbol{f}_{y k}} \boldsymbol{b d} \geq 0.0013 \boldsymbol{b d} \\
& g=\boldsymbol{M}_{\boldsymbol{u}}\left(\boldsymbol{A}_{\boldsymbol{s}, \min }\right)-\boldsymbol{M}_{\boldsymbol{c r}}
\end{aligned}
$$

It can be observed that $\beta$ against brittle failure in RC elements with minimum reinforcement ranges between 1.50 and 1.80 . Hence, if the criterion of providing similar reliability to FRC as current $\mathrm{RC}$ design is accepted, the safety factor $\gamma_{f R 3 k}$ using Eq. 9 would be between 1.50 and 1.75, depending on the $\mathbf{C V}$ of the $f_{R 3}$.

\section{CONCLUSIONS}

This study propose an alternative approach to consider the influence of the scatter and the safety coefficients applied to the design of precast FRC tunnel segments. A structural reliability analysis was conducted with the traditional safety format including the minimal ductility response criteria in case of failure and the variability of the mechanical properties of the material. Based on the analysis of the results, the following conclusions can be drawn.

- The increase of the cracked area in FRC elements should lead to a reduction of the standard deviation with respect to that measured in small-scale tests. These observations derived from the simplified simulation conducted here agree with those found by Cavalaro and Aguado (2015). In fact, similar curves were obtained for the reduction of the scatter despite the significant difference regarding the simulation used in both studies. The results also confirm that the influence of the size does not affect the average and the scatter by the same extent.

- The influence of the size of the FRC element in the scatter should be applied exclusively to the standard deviation, not to the average residual strength. This contradicts the approach proposed 
by DAfStb where the correction is applied to the characteristic value, thus affecting both the average and the standard deviation measured in the small-scale 3-PBT. Such assumption might cause inconsistencies, particularly in large FRC elements which could have equivalent characteristic residual flexural strengths bigger than the average residual strength measured in small-scale 3-PBT.

- The partial safety factor $\gamma_{f R 3 k}$ to provide similar reliability index against brittle failure as that accepted for RC structures with minimum mechanical reinforcement, according to EC-2, ranges between 1.50 and 1.75 .

- Eq. 9 may be used to assess $\gamma_{f R 3 k}$ for specific cases of FRC elements reinforced solely with fibres (not only tunnel segments). This equation should lead to acceptable results as long as the design bending moment is smaller than the cracking bending moment and regarded the limitations in terms of ranges of input parameters mentioned in section 4 .

Additional research is still needed to establish the optimum value of $\boldsymbol{\beta}$ to be considered for design of FRC elements taking into account economic, environmental and social requirements.

\section{ACKNOWLEDGEMENTS}

The authors wish to express their gratitude to the Spanish Ministry of Economy, Industry and Competitiveness for the economic support in the scope of the project SAES (BIA201678742-C2-1-R).

\section{REFERENCES}

1. Abbas, S., Soliman, A., Nehdi, M., 2014. Structural behaviour of ultra-high performance fibre reinforced concrete tunnel lining segments. FRC 2014 Joint ACI-fib International Workshop. Fibre Reinforced Concrete Applications. 24-25 July 2014, Montreal, Canada, 532 - 543.

2. ACI 544.7R-16 Report on Design and Construction of Fiber-Reinforced Precast Tunnel Segments.

3. Arnau, O., Molins, C., 2011. Experimental and analytical study of the structural response of segmental tunnel linings based on an in situ loading test. Part 2: Numerical Simulation. Tunn. Undergr. Space Technol. 26, 778-788.

4. Arnau, O., Molins, C., 2012. Three dimensional structural response of segmental tunnel linings. Eng. Struct. 44, 210-221.

5. Arnau, O., Molins, C., 2015. Theoretical and numerical analysis of the three-dimensional response of segmental tunnel linings subjected to localized loads. Tunn. Undergr. Space Technol. 49, 384-399.

6. Bazant, Z. Size Effect in Blunt Fracture: Concrete, Rock, Metal. Journal of Engineering Mechanics. Vol. 110, Issue 4. pp. 518-536. 1984

7. Blanco, A., Pujadas, P., de la Fuente, A., Cavalaro S., Aguado, A., 2013. Application of constitutive models in European codes to RC-FRC. Constr. Build. Mater. 40, 246-259.

8. Blanco, A., Pujadas, P., de la Fuente, A., Cavalaro, S.H.P., Aguado, A., 2015. Assessment of the fiber orientation factor in SFRC slabs. Composit. Part B. 68, 343-354.

9. Bittencourt, T., Figueiredo, A., Bitencourt, L., Galobardes, I., Fernandes, J., Monte, R., Almeida, A.P., 2016. Mechanical behaviour and durability assessment of precast concrete segments for TBM-constructed tunnels. Report CMSP, São Paulo-Metro Line 5. Universidade Politécnica de São Paulo. May 2016.

10. Blazejowsky, M., 2012. Flexural behaviour of steel fibre reinforced concrete tunnel linings. The University of Western Ontario. Electronic Thesis and Dissertation Repository. Paper 768.

11. Caratelli, A., Meda, A., Rinaldi, Z., Romualdi, P., 2011. Structural behaviour of precast tunnel segments in fibre reinforced concrete. Tunn. Undergr. Space Technol. 26(2), 284-291.

12. Caratelli, A., Meda, A., Rinaldi, Z., 2012. Design according to MC2010 of fibre-reinforced concrete tunnel in Monte Lirio, Panama. Struct. Conc. 13(3), 166-173. 
13. Carmona, S., Molins, C., Aguado, A., Mora, F., 2016. Distribution of fibres in SFRC segments for tunnel linings. Tunn. Undergr. Space Technol. 51, 238-249.

14. Carpinteri, A., Cadamuro, E., Corrado, M., 2014. Minimum flexural reinforcement in rectangular and Tsection concrete beams. Struct. Conc. 15(3): 361-372.

15. Cavalaro, S.H.P., Blom, C.B.M., Aguado, A., Walraven, J.C., 2012. New Design Method for the Production Tolerances of Concrete Tunnel Segments. J Perfor. Const. Facilit. 26(6), 824-834.

16. Cavalaro, S.H.P., Blom, C.B.M., Walraven, J.C., Aguado, A., 2012. Formation and accumulation of contact deficiencies in a tunnel segmented lining. Appl. Math. Model. 36(9), 4422-4438.

17. Cavalaro, S.H.P., Aguado, A., 2015. Intrinsic scatter of FRC: an alternative philosophy to estimate characteristic values. Mater. Struct. 48, 3537-3555.

18. Cavalaro, S.H.P., López, R., Torrents, J.M., Aguado, A., 2015. Improved assessment of fibre content and orientation with inductive method in SFRC. Mater. Struct. 48, 1859-1873.

19. Cervenka, V., 2013. Reliability-based non-linear analysis according to fib Model Code 2010. Struct. Concr. $14,19-28$.

20. Chiaia, B., Fantilli, A.F., Vallini, P., 2009. Combining fibre-reinforced concrete with traditional reinforcement in tunnel linings. Eng. Struct. 31(7), 1600-1606.

21. Chiaia, B., Fantilli, A.P., Vallini, P., 2009. Evaluation of minimum reinforcement ratio in FRC members and application to tunnel linings. Mater. Struct. 42(3), 339-351.

22. Colombo, M., Martinelli, P., di Prisco M., 2015. A design approach for tunnels exposed to blast and fire. Struct Concr. 16(2), 262-272.

23. Colombo, M., Martinelli, P., di Prisco, M., 2016. On the blast resistance of high performance tunnel segments. Mater. Struct. 49, 117-131.

24. Conforti, A., Tiberti, G., Plizzari, G.A., 2016. Splitting and crushing failure in FRC elements subjected to high concentrated loads. Composties Part B 105, 82-92.

25. de la Fuente A., Blanco A., Pujadas P., Aguado, A., 2012. Experiences in Barcelona with the use of fibres in segmental linings. Tunn. Undergr. Space Technol. 27(1), 60-71.

26. de la Fuente, A., Aguado, A., Molins, C., Armengou, J., 2012. Numerical model for the analysis up to failure of precast concrete sections. Comput Struct. 106-107, 105-14.

27. de la Fuente, A., Blanco, A., Armengou, J., Aguado, A., 2017. Sustainability based-approach to determine the concrete type and reinforcement configuration of TBM tunnel linings. Case study: extension line to Barcelona Airport T1. Tunn. Undergr. Space Technol. 61, 179-188.

28. di Carlo, F., Meda A., Rinaldi, Z., 2016. Design procedure for precast fibre-reinforced concrete segments in tunnel lining construction. Struct. Conc. 17(5), 747-759.

29. di Prisco, M., Martinelli, P., Parmentier, B., 2016. On the reliability of design approach for FRC structures according to Model Code 2010: the case of elevated slabs. Struct. Conc. 17(4), 588-602.

30. di Prisco, M., Martinelli, P., Dozio, D., 2016. The structural redistribution coefficient KRd: a numerical approach to its evaluation. Struct. Conc. 17(3), 390-407.

31. EN 1990:2002+A1:2005. Eurocode - Basis of structural design. CEN 2011.

32. EN 14651:2005. Test method for metallic fibered concrete. Measuring the flexural tensile strength (limit of proportionality (LOP), residual).

33. EN 1992:2004. "Eurocode 2: Design of concrete structures: Part 1-1: General rules and rules for buildings", Brussels.

34. European Concrete Patform ASBL (2008), "Eurocode 2 Commentary", Brussels.

35. Galeote E., Blanco A., de la Fuente A. Effect of reinforcement configuration on the ductility requirements of real-scale slabs. $3^{\text {rd }}$ FRC International Workshop Fibre Reinforced Concrete: from Design to Structural Applications. 28-30 June 2018, Desenzano, Lake Garda (Italy). pp. 26.27.

36. Fantilli, A.P., Chiaia, B., Gorino, A., 2016. Volume fraction and ductility index of concrete beams. Cem. Conc. Comp. 65, 139-149.

37. Fantilli, A.P., Chiaia, B., Gorino, A., 2016. Unified approach for minimum reinforcement of concrete beams. ACI Structural Journal 113(5), 1107-1116.

38. fib Bulletins 65-66 (2010), Model Code 2010. fédération internationale du béton (fib), Lausanne (Switzerland).

39. fib Bulletin 83 (2017). Precast tunnel segments in fibre-reinforced concrete (State-of-the-art Report). fib Working Group 1.4.1. Fédération internationale du béton (fib), Lausanne (Switzerland). 
40. Gettu, R., Barragán, B., García, T., Ramos, G., Fernández, C., Oliver, R., 2004. Steel Fiber Reinforced Concrete for the Barcelona Metro Line 9 Tunnel Lining. In BEFIB 2004, Proc of the 6th RILEM Symposium on FRC, Varenna (Italy), September 20-22, RILEM PRO 39, 141-156.

41. ITATECH Activity Group Support. ITA-TECH design guidance for precast fibre reinforced concrete segments. July, 2015. Draft Report.

42. JCSS (2001). JCCS: Probabilistic model code. The Joint Committee on Structural Safety.

43. Kim J-K. Size effect in concrete specimens with dissimilar initial cracks. Magazine of Concrete Research 1990 42:153, 233-238

44. Levi, F., 1985. On minimum reinforcement in concrete structures. ASCE J. Struct. Eng. 111(12), 791-2796.

45. Liao, L., de la Fuente, A., Cavalaro, S., Aguado, A., 2015a. Design of FRC tunnel segments considering the ductility requirements of the MC 2010. Tunn. Undergr. Space Technol. 47(3), 200-210.

46. Liao, L., de la Fuente, A., Cavalaro, S., Aguado, A., Carbonari, G., 2015b. Experimental and analytical study of concrete blocks subjected to concentrated loads with an application to TBM-constructed tunnels. Tunn. Undergr. Space Technol. 49(1), 295-306.

47. Liao, L., de la Fuente, A., Cavalaro, S.H.P., Aguado, A., 2016. Design procedure and experimental study on fibre reinforced concrete segmental rings for vertical shafts. Mat. \& Design 92, 590-601.

48. Lilliu, G., Meda, A., 2013. Nonlinear phased analysis of reinforced concrete tunnels under fire exposure. Journal of Sructural Fire Eng. 3, 4, 131-142.

49. Meda, A., Rinaldi, Z., Caratelli, A., Cigniti, F., 2016. Experimental investigation of precast tunnel segments under TBM thrust action. Tunn. Undergr. Space Technol. 119, 174-185.

50. Melchers, R.E., 1999. Structural Reliability Analysis and Prediction, Second Edition John Wiley \& Sons, Chichester.

51. Molins, C., Aguado, A., Saludes, S., 2009. Double punch test to control the energy dissipation in tension of FRC (Barcelona test). Mater. Struct. 42(4), 415-425.

52. Molins, C., Arnau, O., 2011. Experimental and analytical study of the structural response of segmental tunnel linings based on an in situ loading test. Part 1: Test Configuration and Execution. Tunn. Undergr. Space Technol. 26, 764-777.

53. Plizzari, G.A., Tiberti, G., 2006. Steel fibers as reinforcement for precast tunnel segments. Tunn. Undergr. Space Technol. 21(3), 438-439.

54. Poh, J., Tan K.H., Peterson, G.L., Wenm, D., 2009. Structural testing of steel fibre reinforced concrete (SFRC) tunnel lining segments in Singapore, WTC 2009, Budapest, Hungary.

55. Pujadas, P., Blanco, A., Cavalaro, S., de la Fuente, A., Aguado, A., 2013. New analytical model to generalize the Barcelona test using axial displacement. J Civ Eng Manage. 19(2), 259-271.

56. Pujadas P., Blanco A., Cavalaro S.H.P., de la Fuente A., Aguado A., 2014. Multidirectional double punch test to assess the post-cracking behaviour and fibre orientation of FRC. Constr. Build. Mater. 58, $214-224$.

57. Schlune, H., Plos, M., Gylltoft, K., 2011. Safety formats for nonlinear analysis tested on concrete beams subjected to shear forces and bending moments. Engineering Struct. 33(8), 2350-2356.

58. Sorelli, L., Toutlemonde, F., 2005. On the design of Steel Fiber Reinforced Concrete tunnel lining segments, $11^{\text {th }}$ International Conference on Fracture 2005, ICF11, 8, 5702-5707.

59. Torrents, J.M., Blanco, A., Pujadas, P., Aguado, A., Juan-García, P., Sánchez-Moragues, M.A., 2012. Inductive method for assessing the amount and orientation of steel fibers in concrete. Mater. Struct. 45(10), 1577-1592.

60. van Vliet, M.R.A., van Mier, J.G.M. Experimental investigation of size effect in concrete and sandstone under uniaxial tension. Engineering Fracture Mechanics 2000, 65(2), 165-188. 